\title{
Article \\ Serbian Organic Food Consumer Research and Bioeconomy Development
}

\author{
Aleksandar Grubor, Nikola Milicevic * and Nenad Djokic \\ Department of Trade, Marketing and Logistics, Faculty of Economics in Subotica, University of Novi Sad, \\ 24000 Subotica, Serbia; agrubor@ef.uns.ac.rs (A.G.); djokicn@ef.uns.ac.rs (N.D.) \\ * Correspondence: milicevic.nikola@ef.uns.ac.rs; Tel.: +381-21-485-2933
}

Received: 21 November 2018; Accepted: 6 December 2018; Published: 17 December 2018

\begin{abstract}
The bioeconomy has been introduced as a potential answer to some of the issues that modern mankind is confronted with: Climate change, industrial restructuring, food security, health, and energy security. In its goal to establish sustainable green growth, the bioeconomy relies heavily on the agriculture and food sector, whereas a special place belongs to organic food. Increasing organic food consumption depends on understanding organic food consumers. Research of their profile, both worldwide and in Serbia, has failed to find their common characteristics. In this paper, results of research with the first application of a logit model in defining domestic organic food consumers are presented. The results showed they were urban, highly educated, and with higher income. The greatest obstacle for increasing their future consumption of organic food was its insufficient availability. The paper provides managerial implications as well.
\end{abstract}

Keywords: bioeconomy; sustainable development; organic food; consumer research; Serbia

\section{Introduction}

Today, with global population growth and an increase in food demand, mankind is confronted with many problems related to climate change, industrial restructuring, food security, health, and energy security. These challenges can be described as persistent, open-ended, complex, and uncertain [1]. However, despite mentioned characterizations, the bioeconomy has been introduced as a potential answer to some of these issues.

Because of its importance, the European Union (EU) developed several programs related to this topic in the early 2000s. Later, in accordance with new societal expectations, the EU established a Strategy on Bioeconomy in 2012. The two most important impacts have been the bioeconomy activity within the program Horizon 2020 and the creation of biobased industries' public-private partnership [2] Although it represents a relatively new concept, bioeconomy in Europe already makes about $17 \%$ of EU GDP and employs around 21.5 million people [3].

In its goal to establish sustainable green growth, the bioeconomy relies heavily on the agriculture and food sector. Hereby, a special place belongs to organic food, food produced by the principles and rules of organic farming. The production and consumption of this food contribute to the environment and consumer protection, influencing one of the main bioeconomy tasks, food security [4].

As for the development of organic food sector in Serbia, the latest available data are from 2016 [5]. According to them, there are 14.358 hectares of organic agricultural land including areas in conversion, and also 1.550 hectares of wild collection. The mentioned agricultural land presents $0.4 \%$ of total agricultural land in the country. The rise of agricultural land area for the last ten years has been 13.528 hectares. The available data show that this area was 8.228 hectares in 2013, 9.548 in 2014, and 15.298 in 2015. In 2016, there were 1.735 organic beehives, 4.607 hectares of organic cereals, 
1.945 hectares of temperate fruit, 36 hectares of organic grapes, 2.857 hectares of organic oilseeds, and 139 hectares of organic vegetables.

When considering different actors at the domestic market, there were 286 producers, 44 processors, 39 importers, and 8 exporters. The value of the exports reached 19 million euros.

Although the increase is evident, organic agriculture has been described [6] as being "hard to achieve a satisfactory level of growth despite great potential and steady growth of main parameters" (p. 9). Furthermore, the same author described that the largest part of organic food is exported, especially to the EU, since Serbian market development (although intensive and evident) is jeopardized by the insufficient increase of consumers' purchasing power. On the other hand, nowadays, organic food is present on the shelves of a majority of retailers, and there is an online offer as well, but the prices are higher, from $50 \%$ to $300 \%$ in comparison to conventional food. Prices of imported organic food products are, in a number of cases, lower than domestic ones. In the structure of supply, there are a lot of imported products, since domestic producers face problems with providing continuity and quantity. Imported products are mostly processed, but there are also fresh products, especially fruit. Fresh products are, however, dominantly from domestic production, especially products of plant origin. Since 2015, organic meat has been present in the domestic market as well. Organic food can be differentiated by the presence of a national organic logo. In such a specific organic food market situation, there is a need to continue researching domestic consumers, since it is, as it is worldwide, a precondition for future organic market development [7].

Previous domestic organic consumer research has differed when attempting to find common characteristics of organic food consumers [8]. There are a number of possible reasons for that [9], a "diversity of settings-from the choice of products whose consumers were researched, choice of samples, geographic focus, time of conduct, choice of segmentation criteria, down to approaches to (methods and techniques of) research into this issue (p. 164)".

Considering the previously described situation, this paper includes the first usage of a logit model in domestic organic food consumers' profile research. The aim of the paper was to research whether the use of this methodological approach contributes to establishing common characteristics of organic food consumers. The first research question was related to comparisons of an organic food consumer profile obtained during this specific research to profiles from previous research. Besides sociodemographic variables, the model included obstacles for organic food consumption. The second research question dealt with the significance of different obstacles preventing increasing organic food consumption. The results could have a significant impact on the marketing management process of domestic organic food suppliers, policymakers, and researchers, all in function of further bioeconomy development as well.

\section{Literature Review}

\subsection{The Bioeconomy}

The first and crucial step in understanding the bioeconomy is related to its defining [10]. The way in which bioeconomy is defined is the starting point for developing and implementing its strategies, legislation, and policies. Bearing in mind that it represents a multidimensional concept, the main question is who is defining it. Economists, farmers, industrials, ecologists, and strategists may have different definitions of bioeconomy, whereas many researchers, governments, and institutions have their own views and explanations for this term [10]. Moreover, the bioeconomy is associated with other terms such as the biobased economy. However, after analyzing several national strategies and policies on this topic, it was indicated by the authors of Reference [11] that whereas a biobased economy is related to "a transformation of the economy as a whole", the bioeconomy is usually understood as a sector.

Although the definition of bioeconomy is not consolidated at the national level (e.g., across EU countries) [12], in a document of the European Commission it is defined as "a key element 
for smart and green growth in Europe, which encompasses the production of renewable biological resources and the conversion of these resources and waste streams into value added products, such as food, feed, bio-based products and bioenergy" (pp. 2-3). Hereby, in addition to improving the management of renewable biological recourses, its establishment may develop new food and biobased product markets [13].

When analyzing the bioeconomy, there is the use of the term sustainability [10], "securing the needs of the current generation without compromising the ability of the next one to secure its own needs" (p. 30). Hence, the bioeconomy is defined [10] as "the sustainable extraction, exploitation, growth, and production of renewable resources from land and sea and their eco-friendly conversion into food, feed, fuels, fibers, chemicals, and materials, to be consumed and recycled in a sustainable manner" (p. 31).

The bioeconomy can be simply related to the production of goods and services from biological (plant, animal, and forest) materials [14]. Moreover, the same author mentioned the bioeconomy in the context of biotechnology and other bioactivities, considering it to be "a new stream of knowledge-based economy".

The bioeconomy can be defined [15] as a political-economic concept that "proposes the replacement of fossil resources by biobased resources in order to address climate change mitigation and counteract resource depletion" (p. 120). According to these authors, innovation is one of the most important factors in realizing a bioeconomy vision. The implementation of bioeconomy innovation systems with adequate policy coordination may increase its competitiveness and bring certain ecological and socioeconomic benefits.

Also pointing to the lack of a consensus of "what a bioeconomy actually implies", a bibliometric analysis has been performed and a literature review carried out on this topic [1]. The authors concluded that the bioeconomy concept has been fragmented across different scientific fields, and identified its three main visions:

- A biotechnology vision, where the focus is on the research, application, and commercialization of biotechnologies in various sectors;

- A bioresource vision, where the focus is on the use and availability of biological resources, as well as on the development of new value chains; and

- A bioecology vision, where the emphasis is on the ecological processes related to energy and nutrients optimization, biodiversity promotion, avoiding monocultures, and the prevention of soil degradation.

Different visions of the bioeconomy can be identified [16]. For this purpose, the authors used a field constituted by the technological dimension (agroecology and industrial biotechnology) and the political-economic dimension (sufficiency and capitalist expansion). Thus, the field was divided into four quadrants, each one corresponding to a combination of the presented dimensions:

- Sustainable capital, characterized by an industrial (bio)technology and the continuation of capitalist expansion, with the key role of technology in all narratives;

- Eco-growth, characterized by agroecology and the capitalist growth economy, with a focus on organic entrepreneurship, small-scale farming, agroecological innovation, and a regional aspect;

- Eco-retreat, combining socioeconomic sufficiency on the one side, and a devotion to ecological agriculture, fishery, and forestry practices on the other; and

- Planned transition, combining a sufficient narrative and industrial (bio)technology.

Despite difficulties in achieving the relation "one concept, one definition", the bioeconomy represents the cure for a sick planet and humanity [10]. However, because of false diagnoses and localized, instead of generalized, therapy, the treatment requires a lot of time. In other words, the process of operationalizing strategy into reality is very complex and demanding. Therefore, in order to achieve wider support, various social spheres (politics, public, industry, and academia) need to be included [3]. 


\subsection{The Bioeconomy and Organic Food}

The bioeconomy provides opportunities to confront some major issues of mankind today, such as natural resource scarcity, climate change, fossil resource dependence, and food security [13]. The development of this concept is of special importance in the agriculture sector as a potential determinant of its sustainable productivity growth [17].

Increasing food demand, caused by global population growth, can be met by establishing an adequate knowledge base that enhances primary production and encourages changes not only in production, but in consumption patterns as well [13]. Moreover, the emphasis should be on the ecological aspect, especially bearing in mind that food production is one of the largest users of fresh water ( $70 \%$ of water consumption goes to agriculture) and that approximately one-third of total global energy demand is required for this sector [18].

Many farmers, besides their role in commodity production, may be considered to be quality food providers and managers of the ecosystem [19]. With adequate land managing, they can participate in providing public goods, of which the type and amount differ depending on farming systems and their practices. From the aspect of a public goods-oriented bioeconomy, among other things, there is the significance of organic farming systems [19]. Following these authors, low-input, agroecological, and organic farming methods have an important role in linking and maintaining on-farm resources (plant genetic diversity, soil fertility, and biocontrol methods).

Contrary to conventional agriculture, which can negatively impact human health and the environment, organic farming respects "the laws of nature" and "the laws of life" [4]. As an alternative to modern, cost- and energy-intensive systems, it includes all practices that result in healthy, high-quality agricultural products without chemical synthesis. Hereby, the emphasis is on food security and the protection of the environment and consumers [4].

\subsection{Organic Food Consumer Profile Research}

It has already been stated that for the future development of organic agriculture, one of the important preconditions is understanding consumers of organic food, whereas there are differences between results of different research considering the domestic organic food consumer profile. Furthermore, reasons for such contradictions have also been stated. Following the already listed arguments, Table 1 illustrates the diversity in settings, implementation, and results of organic food consumer profile research performed in domestic conditions in the last three years [8,9,20-23].

As it can be seen from the table, none of the research until now has used a logit model. The additional value of this research is treating obstacles for increasing consumption as an independent variable.

When compared to some of the research from abroad, domestic research offers partly similar conclusions. Some of the listed domestic research, in which there is a positive relation between higher education and organic food acceptance $[8,20,21,23]$, is in accordance with results of some foreign research [24-27]. Part of the domestic research has pointed out that consumers with higher income accept organic food more readily $[20,21,23]$. The same conclusion has been supported in certain research worldwide [26-29].

In one research project from Serbia, women were suggested to be organic food buyers [9], similarly to some other countries $[30,31]$. The same research stressed relatively older respondents as well as employed people being more in favor of organic food, which was also established abroad [26]. The positive influence of the presence of children in the household on organic food purchases established in this research has also been supported by certain foreign research [25,29]. 
Table 1. Domestic organic food consumers' research.

\begin{tabular}{|c|c|c|c|c|c|c|c|}
\hline Research & Product & Sample & Place & Time & Segmentation Base & Technique & Results \\
\hline [20] & $\begin{array}{l}\text { organic food } \\
\text { in general }\end{array}$ & $\begin{array}{l}\text { convenient sample: } \\
300 \text { respondents, } \\
\text { aged } 18-65\end{array}$ & $\begin{array}{l}\text { Belgrade, Novi Sad, } \\
\text { Subotica, Niš, } \\
\text { Kragujevac, Kraljevo }\end{array}$ & June 2016 & $\begin{array}{l}\text { sociodemographic } \\
\text { variables brought in } \\
\text { connection to frequency } \\
\text { of organic food } \\
\text { consumption }\end{array}$ & $\begin{array}{l}\text { tests of differences } \\
\text { and relationships }\end{array}$ & $\begin{array}{l}\text { More educated respondents and respondents with } \\
\text { higher income consume or preferred to consume } \\
\text { organic food more frequently. }\end{array}$ \\
\hline [21] & $\begin{array}{l}\text { (seems) } \\
\text { organic food } \\
\text { in general }\end{array}$ & $\begin{array}{l}\text { convenient sample: } \\
212 \text { respondents }\end{array}$ & $\begin{array}{l}\text { online and personal in } \\
\text { Belgrade, Novi Sad, Niš, } \\
\text { Kragujevac, Novi Pazar }\end{array}$ & May and June 2014 & $\begin{array}{l}\text { sociodemographic } \\
\text { variables brought in } \\
\text { connection to frequency } \\
\text { of organic food } \\
\text { consumption }\end{array}$ & test of differences & $\begin{array}{l}\text { More educated respondents and respondents with } \\
\text { higher income, as well as those who work in } \\
\text { education, health, and public institutions, often } \\
\text { purchased organic food. }\end{array}$ \\
\hline [9] & $\begin{array}{l}\text { (organic) } \\
\text { yogurt }\end{array}$ & $\begin{array}{l}\text { chain referral } \\
\text { sampling: } 400 \\
\text { respondents that } \\
\text { were } 18-30 \text { years old }\end{array}$ & Serbia & $\begin{array}{l}\text { from May } 2014 \text { until } \\
\text { July } 2014\end{array}$ & $\begin{array}{l}\text { preferences toward } \\
\text { different yogurt } \\
\text { attributes including } \\
\text { being organic or not }\end{array}$ & $\begin{array}{l}\text { conjoint and } \\
\text { cluster analyses, } \\
\text { tests of differences }\end{array}$ & $\begin{array}{l}\text { Those preferring organic yogurt were mostly } \\
\text { female, relatively more mature, employed, married, } \\
\text { and had children. They valued the importance of } \\
\text { diet for health, and had experience with a disease of } \\
\text { a close person, which was believed that it could } \\
\text { have been prevented by proper diet. They did the } \\
\text { least sports. }\end{array}$ \\
\hline [22] & $\begin{array}{l}\text { organic food } \\
\text { in general }\end{array}$ & $\begin{array}{l}260 \text { respondents } \\
\text { (from Serbia) }\end{array}$ & Serbia (and Croatia) & no data & $\begin{array}{l}\text { gender brought in } \\
\text { relation to statement } \\
\text { about using organic } \\
\text { everyday }\end{array}$ & test of differences & Men consumed organic food more frequently. \\
\hline [23] & $\begin{array}{l}\text { organic food } \\
\text { in general }\end{array}$ & 398 respondents & online in Serbia & $\begin{array}{l}\text { from March until } \\
\text { December } 2016\end{array}$ & $\begin{array}{l}\text { sociodemographic } \\
\text { variables brought in } \\
\text { connection to scale } \\
\text { measuring different } \\
\text { levels of willingness to } \\
\text { pay more money for } \\
\text { organic food }\end{array}$ & test of differences & $\begin{array}{l}\text { Men and women from towns, with a family of up to } \\
\text { four persons, more educated, and within the income } \\
\text { range of } 500-2000 \text { euros per month were willing to } \\
\text { pay up to } 20 \% \text { higher price for organic food. }\end{array}$ \\
\hline [8] & $\begin{array}{l}\text { organic food } \\
\text { in general }\end{array}$ & $\begin{array}{l}\text { convenient sample: } \\
420 \text { respondents that } \\
\text { were } 18-65 \text { years old } \\
\text { and that were in } \\
\text { charge of cooking or } \\
\text { buying food in the } \\
\text { household }\end{array}$ & $\begin{array}{l}\text { simultaneously in } \\
\text { several larger Serbian } \\
\text { towns, as well as in the } \\
\text { city of Belgrade }\end{array}$ & $\begin{array}{l}\text { from October until } \\
\text { November } 2015\end{array}$ & $\begin{array}{l}\text { similarities in assessing } \\
23 \text { food-related lifestyle } \\
\text { dimensions }\end{array}$ & $\begin{array}{l}\text { cluster analysis, } \\
\text { tests of differences }\end{array}$ & $\begin{array}{l}\text { Adventurous consumers preferred organic food } \\
\text { strongly, they were the most educated, included the } \\
\text { whole family in the preparation of meals, and } \\
\text { accepted novelties in cooking. Low availability, } \\
\text { instead of the price, was the greatest obstacle in } \\
\text { increasing their organic food consumption. }\end{array}$ \\
\hline
\end{tabular}




\section{Methodology}

The questionnaire consisted of two parts. The first part was related to independent variables. This included sociodemographic characteristics: Gender, age, education, marital status, the presence of children in the family, the size of the household, employment status, self-assessed household income, place of residence, and obstacles (if any) for increasing organic food consumption. The second part of the questionnaire was related to consumption of organic food.

Structured interviews by means of personal communication with the respondent with the use of the questionnaire were implemented. A convenience sampling method was chosen. There were collected a total of 344 answers. Data were processed in 2018.

In the sample, $36.3 \%$ were male and $63.7 \%$ were female. The average respondent was 36.82 years old (standard deviation 13.004). As for education, $36.6 \%$ of respondents had finished secondary school, $13.4 \%$ of respondents were attending college or faculty, and $50.0 \%$ had finished college or faculty. When it came to marital status, $62.5 \%$ of respondents were married and $37.5 \%$ were single, and $51.5 \%$ of households had a child or children, and $48.5 \%$ did not. Out of all respondents, $19.2 \%$ were unemployed, $29.7 \%$ were employed by the state, and $51.2 \%$ were employed in the private sector. The average household size was 2.81 (standard deviation 1.303). Regarding household income, the average self-assessment of it was 2.95 (standard deviation 0.799 ). When considering place of residence, $58.7 \%$ lived in urban areas and $41.3 \%$ in rural places. For increasing future organic food consumption, $63.4 \%$ of respondents had no obstacles, $14.5 \%$ found it in its premium price, $17.4 \%$ found it in insufficient availability, and $4.7 \%$ had some issues with regard to trust that it is actually organic food.

Bearing in mind that the actual consumption of organic food was presented through a dichotomous variable, the effects of sociodemographic characteristics and obstacles (independent variables) were analyzed with the use of a logit model. In addition, for more detailed examination of these relations, we relied on the marginal effects concept [32]. Data was processed in STATA statistical package.

\section{Results}

As presented in Table 2, the $p$-value of the logit model was lower than 0.01 (Prob $>$ chi2 $=0.000$ ), confirming its statistical significance. Also, statistically significant coefficients occurred at four out of nine independent variables (Education, Income, and Place at $p<0.05$, and Obstacles at $p<0.1$ ).

Table 2. Logit model.

\begin{tabular}{|c|c|c|c|c|c|c|}
\hline Variables & Coef. & Std. Err. & $Z$ & $P>|z|$ & \multicolumn{2}{|c|}{ [95\% Conf. Interval] } \\
\hline female & 0.3443567 & 0.3614169 & 0.95 & 0.341 & -0.3640074 & 1.052721 \\
\hline Age & -0.0235896 & 0.0166322 & -1.42 & 0.156 & -0.0561881 & 0.0090089 \\
\hline $\begin{array}{l}\text { Marriage } \\
\text { single }\end{array}$ & -0.6501382 & 0.4083067 & -1.59 & 0.111 & -1.450405 & 0.1501282 \\
\hline $\begin{array}{l}\text { Children } \\
\text { with children }\end{array}$ & -0.220322 & 0.4675494 & -0.47 & 0.637 & -1.136702 & 0.696058 \\
\hline Household size & 0.3027054 & 0.1876776 & 1.61 & 0.107 & -0.065136 & 0.6705468 \\
\hline $\begin{array}{l}\text { Education } \\
\text { student } \\
\text { college/faculty }\end{array}$ & $\begin{array}{c}0.8448753 \\
2.536818\end{array}$ & $\begin{array}{l}0.7346766 \\
0.5590311\end{array}$ & $\begin{array}{l}1.15 \\
4.54\end{array}$ & $\begin{array}{l}0.250 \\
0.000\end{array}$ & $\begin{array}{c}-0.5950643 \\
1.441137\end{array}$ & $\begin{array}{l}2.284815 \\
3.632499\end{array}$ \\
\hline $\begin{array}{l}\text { Job } \\
\text { employed by the state } \\
\text { employed by private sector }\end{array}$ & $\begin{array}{l}0.2318935 \\
0.0143765\end{array}$ & $\begin{array}{l}0.5681902 \\
0.5510813\end{array}$ & $\begin{array}{l}0.41 \\
0.03\end{array}$ & $\begin{array}{l}0.683 \\
0.979\end{array}$ & $\begin{array}{l}-0.8817388 \\
-1.065723\end{array}$ & $\begin{array}{l}1.345526 \\
1.094476\end{array}$ \\
\hline Income & 0.4815921 & 0.2306998 & 2.09 & 0.037 & 0.0294289 & 0.9337553 \\
\hline $\begin{array}{l}\text { Place } \\
\text { rural }\end{array}$ & -1.089203 & 0.3577095 & -3.04 & 0.002 & -1.790301 & -0.3881051 \\
\hline $\begin{array}{l}\text { Obstacles } \\
\text { price } \\
\text { availability } \\
\text { trust }\end{array}$ & $\begin{array}{c}-0.9062664 \\
0.6187354 \\
0.588162\end{array}$ & $\begin{array}{l}0.5099154 \\
0.4226282 \\
0.6528566\end{array}$ & $\begin{array}{l}-1.78 \\
1.46 \\
0.90\end{array}$ & $\begin{array}{l}0.076 \\
0.143 \\
0.368\end{array}$ & $\begin{array}{l}-1.905682 \\
-0.2096006 \\
-0.6914133\end{array}$ & $\begin{array}{c}0.0931495 \\
1.447071 \\
1.867737\end{array}$ \\
\hline Cons & -4.274911 & 1.388486 & -3.08 & 0.002 & -6.996293 & -1.553528 \\
\hline Number of obs. $=344 ; \log$ like & $\mathrm{d}=-126.9$ & 21; LR chi2 & $=88.22$ & $o b>c h i 2$ & .000 ; pseudo & $22=0.2579$ \\
\hline
\end{tabular}


Besides the estimated coefficients, the concept of marginal effects was applied. Their values are shown in Table 3.

Table 3. Marginal effects.

\begin{tabular}{lcccccc}
\hline \multicolumn{1}{c}{ Variables } & $d y / d x$ & Std. Err. & $z$ & $P>|z|$ & [95\% Conf. Interval] \\
\hline $\begin{array}{l}\text { Gender } \\
\text { female }\end{array}$ & 0.0395329 & 0.0408104 & 0.97 & 0.333 & -0.0404541 & 0.1195198 \\
\hline Age & -0.0027391 & 0.0019083 & -1.44 & 0.151 & -0.0064793 & 0.001001 \\
\hline $\begin{array}{l}\text { Marriage } \\
\quad \text { single }\end{array}$ & -0.0741746 & 0.0451212 & -1.64 & 0.100 & -0.1626105 & 0.0142613 \\
\hline $\begin{array}{l}\text { Children } \\
\text { with children }\end{array}$ & -0.0254644 & 0.0537769 & -0.47 & 0.636 & -0.1308653 & 0.0799365 \\
\hline Household size & 0.035149 & 0.0215501 & 1.63 & 0.103 & -0.0070885 & 0.0773865 \\
\hline $\begin{array}{l}\text { Education } \\
\quad \text { student } \\
\text { college/faculty }\end{array}$ & 0.0521344 & 0.0507467 & 1.03 & 0.304 & -0.0473272 & 0.1515961 \\
\hline $\begin{array}{l}\text { Job } \\
\text { employed by the state }\end{array}$ & 0.2819929 & 0.0500208 & 5.64 & 0.000 & 0.1839541 & 0.3800318 \\
$\quad$ employed in private sector & 0.0273759 & 0.0662232 & 0.41 & 0.679 & -0.1024192 & 0.1571711 \\
\hline $\begin{array}{l}\text { Income } \\
\text { Place }\end{array}$ & 0.0016323 & 0.0624949 & 0.03 & 0.979 & -0.1208555 & 0.1241201 \\
$\quad 0.0559206$ & 0.0260767 & 2.14 & 0.032 & 0.0048113 & 0.10703 \\
\hline $\begin{array}{l}\text { Obstacles } \\
\text { price } \\
\text { availability } \\
\text { trust }\end{array}$ & -0.123906 & 0.0379394 & -3.27 & 0.001 & -0.1982658 & -0.0495462 \\
\hline
\end{tabular}

As in the case of coefficients, statistically significant marginal effects were obtained for the same four independent variables. Thus, in further analysis, the emphasis was on these four regressors (Education, Income, Place, and Obstacles).

When it came to Education, the highest average probability of organic food consumption was recorded for those who finished college or faculty $(0.330, p<0.05)$, followed by students $(0.100, p<0.05)$ and those who finished secondary schools $(0.048, p<0.05)$. Their relations are presented in Figure 1.

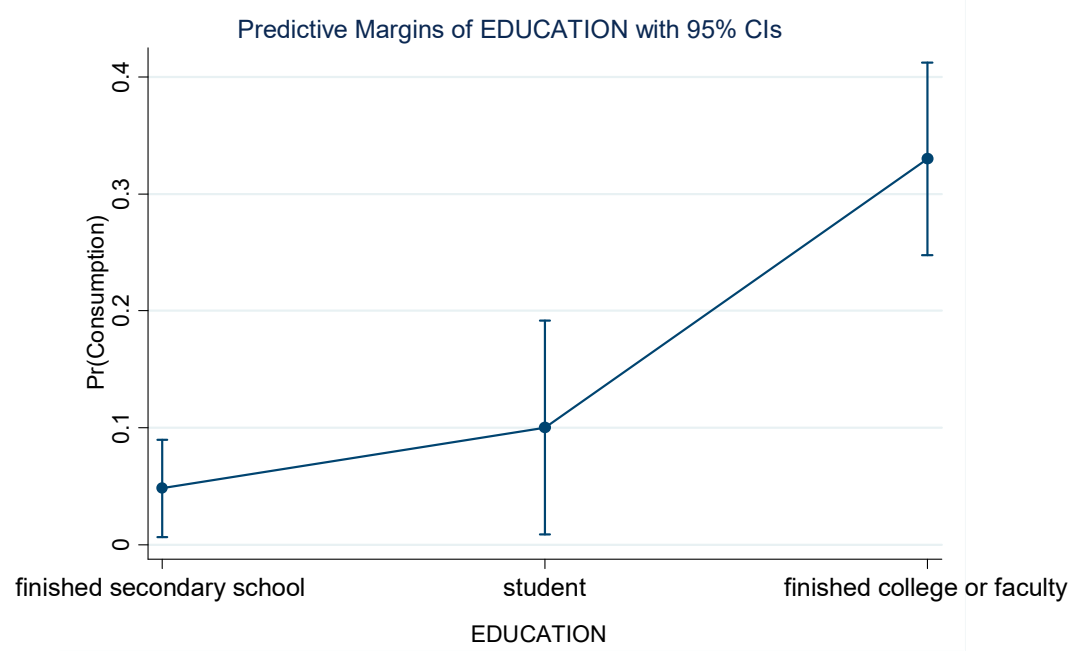

Figure 1. Education: Average probabilities.

As shown in Table 4 , the differences between the average probability of organic food consumption for highly educated people and the average probabilities for other two educational levels were statistically significant at $p<0.05$. On the other hand, this was not the case when considering the difference between students and those who finished secondary school $(p=0.304)$. 
Table 4. Education: marginal effects.

\begin{tabular}{cccccccc}
\hline \multicolumn{2}{c}{ Education } & \multicolumn{1}{c}{$d y / d x$} & Std. Err. & $z$ & $P>z$ & \multicolumn{2}{c}{ [95\% Conf. Interval] } \\
\hline \multirow{2}{*}{ secondary school } & student & 0.0521344 & 0.0507467 & 1.03 & 0.304 & -0.0473272 & 0.1515961 \\
& college or faculty & 0.2819929 & 0.0500208 & 5.64 & 0.000 & 0.1839541 & 0.3800318 \\
\hline \multirow{2}{*}{ student } & secondary school & -0.0521344 & 0.0507467 & -1.03 & 0.304 & -0.1515961 & 0.0473272 \\
& college or faculty & 0.2298585 & 0.0688801 & 3.34 & 0.001 & 0.094856 & 0.364861 \\
\hline \multirow{2}{*}{ college or faculty } & secondary school & -0.2819929 & 0.0500208 & -5.64 & 0.000 & -0.3800318 & -0.1839541 \\
& student & -0.2298585 & 0.0688801 & -3.34 & 0.001 & -0.364861 & -0.094856 \\
\hline
\end{tabular}

In relation to the Income variable, the average probabilities of organic food consumption were calculated for five different levels. Whereas at the first level it was $0.097(p<0.05)$, at the fifth it was more than three times higher $(0.326, p<0.05)$. Thus, with the increase in income, the likelihood of organic food consumption increased as well (Figure 2).

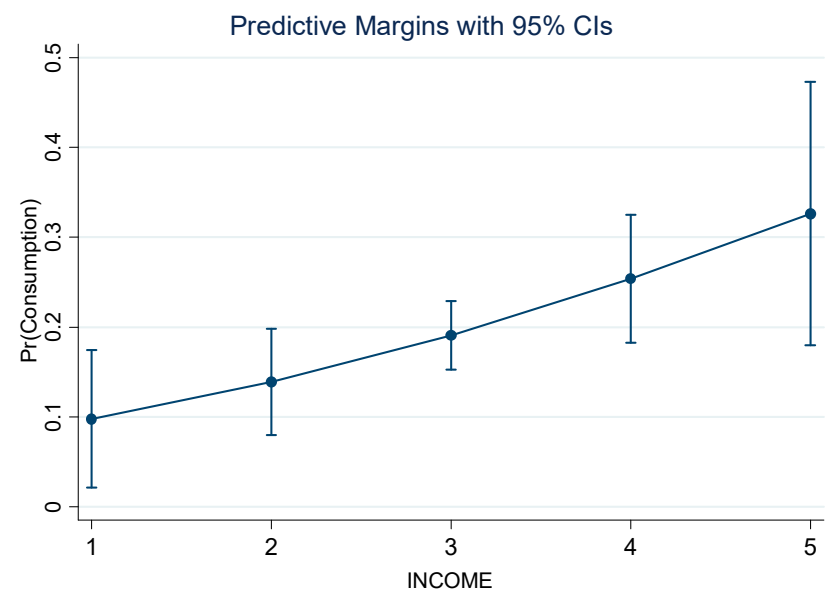

Figure 2. Income: Average probabilities.

In the case of the Place variable, the average probability of organic food consumption related to urban places was $0.250(p<0.05)$. It was almost twice as high as the average probability in rural places $(0.126, p<0.05)$, as can be seen in Figure 3. Their difference of 0.123 was statistically significant at $p<0.05$.

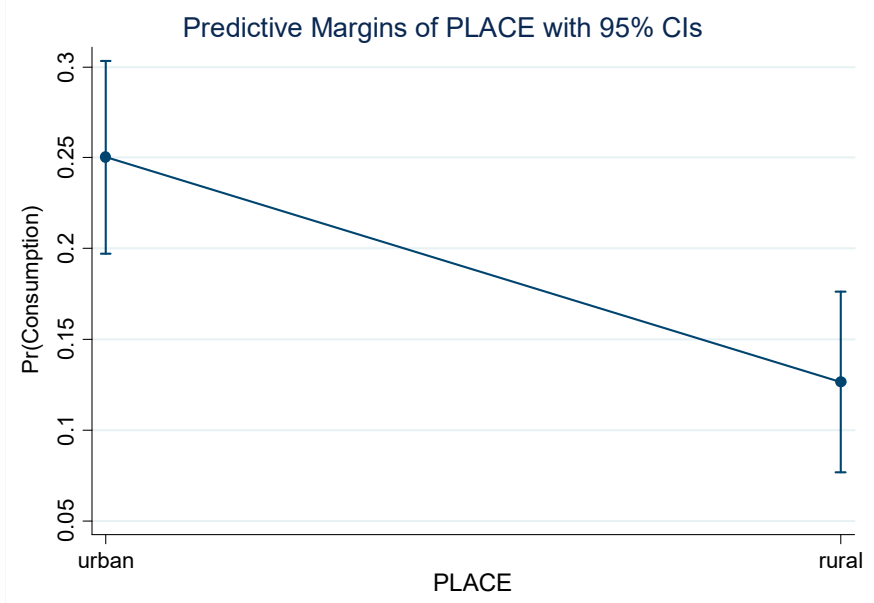

Figure 3. Place: Average probabilities. 
When considering Obstacles, average probabilities of organic food consumption were calculated in four cases: When there were no obstacles or when price, availability, or trust in the organic origin of a product presented the obstacle. Their values can be seen in Figure 4.

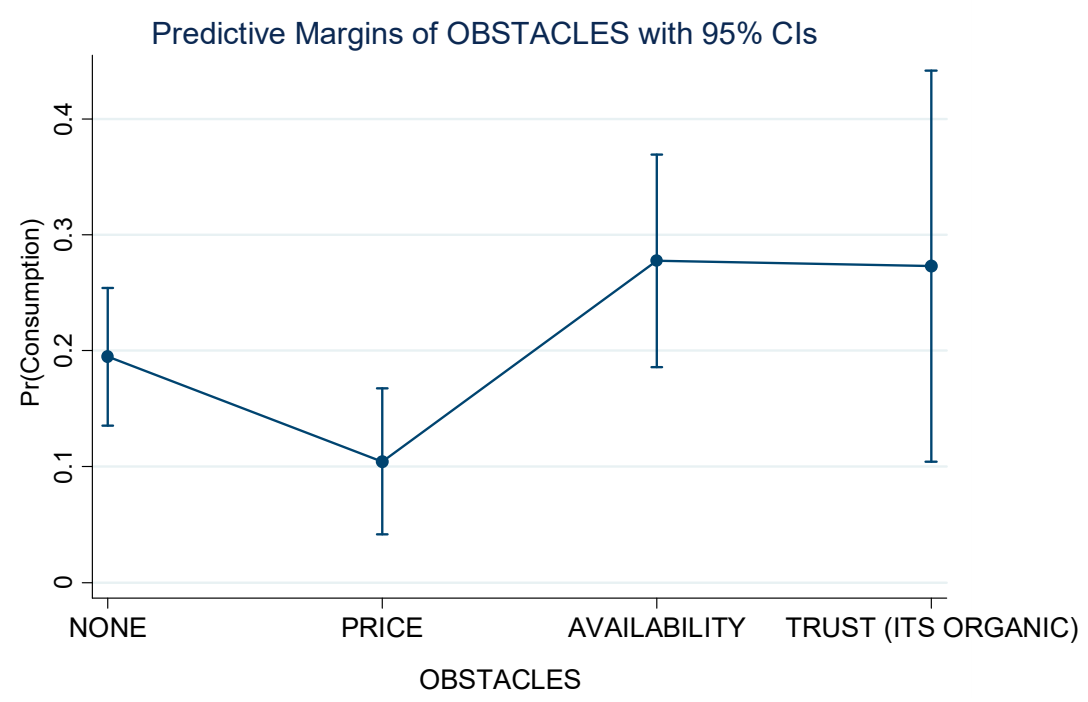

Figure 4. Obstacles: Average probabilities.

The highest average probabilities corresponded to availability (0.277) and trust (0.272). On the other hand, its smallest value was recorded for price as an obstacle (0.104). In the case when there were no obstacles, the average probability of organic food consumption was 0.194 . Hereby, all predicted probabilities were statistically significant at $p<0.05$.

As shown in Table 5 , the differences in average probability of organic food consumption with price on one side and the remaining options on another were statistically significant at $p<0.05$ (with availability) and $p<0.1$ (with no obstacles and trust). In other words, for those who consumed organic food, price did not represent an important obstacle. They were more confronted with problems concerning its availability.

Table 5. Obstacles: Marginal effects.

\begin{tabular}{cccccccc}
\hline \multicolumn{2}{c}{ Obstacles } & $d y / d x$ & Std. Err. & $z$ & $P>z$ & \multicolumn{2}{c}{ [95\% Conf. Interval] } \\
\hline \multirow{4}{*}{ none } & price & -0.0903981 & 0.046109 & -1.96 & 0.050 & -0.1807702 & -0.0000261 \\
& availability & 0.0824362 & 0.0590516 & 1.40 & 0.163 & -0.0333029 & 0.1981752 \\
& trust & 0.0780211 & 0.0925272 & 0.84 & 0.399 & -0.1033288 & 0.259371 \\
\hline \multirow{3}{*}{ price } & none & 0.0903981 & 0.046109 & 1.96 & 0.050 & 0.0000261 & 0.1807702 \\
& availability & 0.1728343 & 0.0558762 & 3.09 & 0.002 & 0.0633189 & 0.2823497 \\
& trust & 0.1684192 & 0.0915894 & 1.84 & 0.066 & -0.0110928 & 0.3479313 \\
\hline \multirow{3}{*}{ availability } & none & -0.0824362 & 0.0590516 & -1.40 & 0.163 & -0.1981752 & 0.0333029 \\
& price & -0.1728343 & 0.0558762 & -3.09 & 0.002 & -0.2823497 & -0.0633189 \\
& trust & -0.0044151 & 0.0958133 & -0.05 & 0.963 & -0.1922057 & 0.1833755 \\
\hline \multirow{4}{*}{ trust } & none & -0.0780211 & 0.0925272 & -0.84 & 0.399 & -0.259371 & 0.1033288 \\
& price & -0.1684192 & 0.0915894 & -1.84 & 0.066 & -0.3479313 & 0.0110928 \\
& availability & 0.0044151 & 0.0958133 & 0.05 & 0.963 & -0.1833755 & 0.1922057 \\
\hline
\end{tabular}

\section{Discussion and Conclusions}

The results of the research pointed out organic food consumers as being more educated and with higher income. Furthermore, these consumers predominantly lived in urban places. Finally, the greatest obstacle for increasing their consumption was low availability of organic food. 
These results were partly in accordance with previous domestic research. When it came to the positive influence of education, the results were consistent with findings from References [8,20,21,23]. As for the positive influence of income, the results corresponded with References [20,21,23]. When considering their urban residence, this was in accordance with Reference [23]. Finally, low availability of organic food as the greatest obstacle for increasing its consumption was in accordance with Reference [8].

Previously listed results were in accordance with some of the research worldwide when it came to the influence of education [24-27] and income [26-29], but also when it came to lack of influence of gender $[24,26-28]$ and age $[28,30,31]$.

However, the results of this research did not support Reference [9] in regard to certain variables' influence, since the authors claimed that those who preferred organic food were female, relatively more mature, employed, married, and had children, nor Reference [22], which described men as being more in favor of organic food, as well as Reference [23], which found gender and family size to be important descriptors.

The main contribution of this paper was the use of a logit model in market segmentation. It is the first such use in the domestic environment. Furthermore, the fact that the results were in general consistent with previous domestic research provides stronger support for creating managerial implications based on common findings. In order to increase future organic food consumption, it would be beneficial to provide its larger availability at least at those places where urban, more educated, and wealthier consumers buy food. It can be supposed (and additional secondary research could confirm it) that such purchases are dominantly performed once per week in larger retail stores. That leads to the conclusion that during the weekends at those stores, separate corners with organic food offers could be established. Hereby, actors from the supply side of the organic food market should do their best to create the widest possible offer. Furthermore, using the media that the described segment is in contact with, as well as precise targeting in social media, should be for the function of informing these consumers where to buy organic food. Allowing online offerings of organic food could also help resolve the problem of consumers wanting to buy more. Finally, as part of the attempts to reach future markets, promotions at university centers could be organized.

The implications of the results of the research can be observed at the level of policymakers as well. Although not the most important, low trust in organic food represents an important obstacle for its consumption. Part of that problem could be caused by organic food being imported from different countries abroad. It would be beneficial for policymakers' support for organic food market future development to increase information about the process of certification and control of imported products, as well as how to recognize the organic logo. Furthermore, they could perform actions in promoting trust in online sales of organic food, thus overcoming the problem with availability. Their support for promoting organic food purchases by the future market at universities could also be of great importance. The significance of their actions in regard to domestic organic food production should not be considered only from the aspect of establishing trust in certified domestic organic food. The increase of the domestic organic food presence at the domestic market could prevent certain problems arising from situations in which organic food export is far dominant in the sense of potentially weakening positions at foreign markets because of the arrival of cheaper competitors from third countries. As for the researchers, the paper points to the support of using new approaches in the research of organic food consumers' profiles. If it is possible to implement different approaches at the database from this single research, there could be obtained comparable insights into the question. Future research could use variable interactions and try to reach a larger or more representative sample.

Author Contributions: All of the authors formulated the goals of the research and interpreted available literature. Conducting and analyzing research was performed by N.M. and N.D., whereas implications were developed by A.G.

Funding: This research received no external funding.

Conflicts of Interest: The authors declare no conflicts of interest. 


\section{References}

1. Bugge, M.M.; Hansen, T.; Klitkou, A. What Is the Bioeconomy? A Review of the Literature. Sustainability 2016, 8, 691. [CrossRef]

2. Patermann, C.; Aguilar, A. The origins of the bioeconomy in the European Union. New Biotechnol. 2017, 40, 20-24. [CrossRef] [PubMed]

3. Kircher, M. The transition to a bio-economy: National perspectives. Biofuels Bioproducts Biorefining 2012, 6 , 240-245. [CrossRef]

4. Canja, C.M.; Boeriu, A.E.; Măzărel, A. Bioeconomy and food safety security. In Proceedings of the 7th International Conference on Computational Mechanics and Virtual Engineering, COMEC 2017, Brasov, Romania, 16-17 November 2017.

5. Willer, H.; Lernoud, J. The World of Organic Agriculture-Statistics and Emerging Trends 2018; Research Institute of Organic Agriculture FiBL: Frick, Switzerland; Organics International IFOAM: Bonn, Germany, 2018; pp. 1-348. ISBN 978-3-03736-068-2.

6. Simic, I. Organic Agriculture in Serbia At a Glance 2017; National Association Serbia Organica: Belgrade, Serbia, 2017; pp. 1-59. ISBN 978-86-88997-09-6.

7. Hughner, R.S.; McDonagh, P.; Prothero, A.; Shultz, C.J.; Stanton, J. Who are organic food consumers? A compilation and review of why people purchase organic food. J. Consum. Behav. 2007, 6, 94-110. [CrossRef]

8. Djokic, N.; Grubor, A.; Milicevic, N.; Petrov, V. New Market Segmentation Knowledge in the Function of Bioeconomy Development in Serbia. Amfiteatru Econ. 2018, 20, 700-716. [CrossRef]

9. Grubor, A.; Djokic, N. Organic food consumer profile in the Republic of Serbia. Br. Food J. 2016, 118, $164-182$. [CrossRef]

10. Sillanpää, M.; Ncibi, C. A Sustainable Bioeconomy: The Green Industrial Revolution; Springer: Cham, Switzerland, 2017; pp. 1-343. ISBN 978-3-319-55637-6.

11. Staffas, L.; Gustavsson, M.; McCormick, K. Strategies and Policies for the Bioeconomy and Bio-Based Economy: An Analysis of Official National Approaches. Sustainability 2013, 5, 2751-2769. [CrossRef]

12. Regional Bioeconomy Profiles Including Socio-Economic and Environmental Impacts: Two Case Studies. Available online: http:/ / www.bio-step.eu/fileadmin/BioSTEP/Bio_documents/BioSTEP_D6.1_Regional_ bioeconomy_profiles.pdf (accessed on 1 October 2018).

13. European Commission. Communication from the Commission to the European Parliament, the Council, the European Economic and Social Committee and the Committee of the Regions: Innovating for Sustainable Growth: A Bioeconomy for Europe; European Commission: Brussels, Belgium, 2012.

14. Ahmed, E.M. Are bio-economy dimensions new stream of the knowledge economy? World J. Sci. Technol. Sustain. Dev. 2017, 15, 142-155. [CrossRef]

15. Asada, R.; Stern, T. Competitive Bioeconomy? Comparing Bio-based and Non-bio-based Primary Sectors of the World. Ecol. Econ. 2018, 149, 120-128. [CrossRef]

16. Hausknost, D.; Schriefl, E.; Lauk, C.; Kalt, G. A Transition to Which Bioeconomy? An Exploration of Diverging Techno-Political Choices. Sustainability 2017, 9, 669. [CrossRef]

17. Rosegrant, M.W.; Ringler, C.; Zhu, T.; Tokgoz, S.; Bhandary, P. Water and food in the bioeconomy: Challenges and opportunities for development. Agric. Econ. 2013, 44, 139-150. [CrossRef]

18. Bell, J.; Lino, P.; Dodd, T.; Németh, S.; Nanou, C.; Mega, V.; Campos, P. EU ambition to build the world's leading bioeconomy-Uncertain times demand innovative and sustainable solutions. New Biotechnol. 2018, 40, 25-30. [CrossRef] [PubMed]

19. Schmidt, O.; Padel, S.; Levidow, L. The Bio-Economy Concept and Knowledge Base in a Public Goods and Farmer Perspective. Bio-Based Appl. Econ. 2012, 1, 47-64. [CrossRef]

20. Đokić, N.; Milićević, N. Organic consumer profile and obstacles for increasing consumption of organic food in Serbia. Ann. Faculty Econ. Subotica 2016, 53, 65-77.

21. Vehapi, S.; Dolićanin, E. Consumers behavior on organic food: Evidence from the Republic of Serbia. Econ. Agric. 2016, 63, 871-889. [CrossRef]

22. Perić, N.; Vasić-Nikčević, A.; Vujić, N. Consumers attitudes on organic food in Serbia and Croatia: A comparative analysis. Econ. Agric. 2017, 64, 1049-1064. [CrossRef] 
23. Vapa-Tankosić, J.; Ignjatijević, S.; Kranjac, M.; Lekić, S.; Prodanović, R. Willingness to pay for organic products on the Serbian market. Int. Food Agribus. Manag. Rev. 2018, 21, 791-801. [CrossRef]

24. Zepeda, L.; Li, J. Characteristics of organic food shoppers. J. Agric. Appl. Econ. 2007, 39, 17-28. [CrossRef]

25. Cicia, G.; Del Giudice, T.; Scarpa, R. Consumers' perception of quality in organic food: A random utility model under preference heterogeneity and choice correlation from rank-orderings. Br. Food J. 2002, 104, 200-213. [CrossRef]

26. Sandalidou, E.; Baourakis, G.; Siskos, Y. Customers' perspectives on the quality of organic olive oil in Greece: A satisfaction evaluation approach. Br. Food J. 2002, 104, 391-406. [CrossRef]

27. Loureiro, M.L.; Hine, S. Discovering niche markets: A comparison of consumer willingness to pay for a local (Colorado-grown), organic, and GMO-free product. J. Agric. Appl. Econ. 2002, 34, 477-487. [CrossRef]

28. Gracia, A.; de Magistris, T. Organic food product purchase behaviour: A pilot study for urban consumers in the South of Italy. Span. J. Agric. Res. 2007, 5, 439-451. [CrossRef]

29. Stolz, H.; Stolze, M.; Janssen, M.; Hamm, U. Preferences and determinants for organic, conventional and conventional-plus products-The case of occasional organic consumers. Food Qual. Prefer. 2011, 22, 772-779. [CrossRef]

30. KoivistoHursti, U.-K.; Magnusson, M. Consumer perceptions of genetically modified and organic foods: What kind of knowledge matters? Appetite 2003, 41, 207-209. [CrossRef]

31. Lockie, S.; Lyons, K.; Grice, J. Choosing organics: A path analysis of factors underlying the selection of organic food among Australian consumers. Appetite 2004, 43, 135-146. [CrossRef] [PubMed]

32. Williams, R. Using the margins command to estimate and interpret adjusted predictions and marginal effects. Stata J. 2012, 12, 308-331. [CrossRef]

(c) 2018 by the authors. Licensee MDPI, Basel, Switzerland. This article is an open access article distributed under the terms and conditions of the Creative Commons Attribution (CC BY) license (http://creativecommons.org/licenses/by/4.0/). 